\title{
Hereditary angioedema type II; report of a case
}

\section{Herediter anjiö̈dem tip II; olgu sunumu}

\section{Sevgi Kesici, Hülya Ulusoy, Yücel Demirci, Selçuk Kayır, Verda Tuna, Uğur Kesici*}

Department of Anesthesiology and Reanimation (S. Kesici, MD, V. Tuna, MD), Kanuni Teaching and Research Hospital, TR-61280 Trabzon, Department of Anesthesiology and Reanimation (H. Ulusoy, MD, Assoc. Prof, Y. Demirci, MD, S. Kayır, MD), Karadeniz Technical University, School of Medicine, TR-61080 Trabzon, General Surgery Clinic (U. Kesici, MD), Akcaabat Haçkalı Baba State Hospital, TR-61300 Trabzon

\begin{abstract}
Hereditary Angioedema is a hereditary disease caused by deficiency or loss of C1 inhibitor (C1INH), with an autosomal dominant inheritance pattern and which may be potentially life threatening. The prevalence of the disease is considerably low. In this case report, a 31 years old woman who has applied to the hospital with an angioedema attack after odontotherapy and who had angioedema attacks for many years with abdominal symptoms in the forefront and as a consequence to whom laparotomy was applied 3 times, is discussed together with literature. Hereditary Angioedema must certainly be considered for patients who apply to hospital with localized angioedema and especially with symptoms relating to upper airway tract and treatment strategy must be determined urgently, because delay in treatment increases morbidity and affects life quality.
\end{abstract}

Keywords: Hereditary, angioedema, type II

\section{Özet}

Herediter Anjioödem, C1 İnhibitör (C1-INH) fonksiyon kaybı veya eksikliği ile ortaya çıkan, otozomal dominant geçişli ve potansiyel olarak yaşamı tehdit edebilen kalıtsal bir hastalıktır. Hastalığın prevelansı oldukça düşüktür. $\mathrm{Bu}$ olgu sunumunda uzun yıllardır abdominal semptomların ön planda olduğu, anjioödem atakları geçiren ve bu nedenle $3 \mathrm{kez}$ laparotomi uygulanan, diş tedavisi sonrası anjioödem atağı ile başvuran 31 yaşında kadın hasta literatür eşliğinde tartışıldı. Lokalize anjioödemle ve özellikle üst havayolunu ilgilendiren semptomlarla başvuran hastalarda herediter anjioödem mutlaka akılda bulundurulmalı, acil tedavi stratejisi belirlenmelidir. Çünkü tedavideki gecikme morbiditeyi arttırır ve yaşam kalitesini olumsuz etkiler.

Anahtar sözcükler: Herediter, anjioödem, tip II

Geliş tarihi/Received: March 11, 2012; Kabul tarihi/Accepted: September 04, 2012

\section{*Corresponding author:}

Dr. Uğur Kesici, Genel Cerrahi Kliniğgi, Akcaabat Haçkalı Baba Devlet Hastanesi, TR-61300 Trabzon. E-posta: ugurkesici77@ mynet.com

\section{Introduction}

Hereditary Angioedema (HAE) was defined clinically by Quincke for the first time in 1882 and its hereditary nature was presented by Osler in 1888 [1]. The prevalence of the disease is considerably low $(1 / 10000-1 / 150000)[1,2]$. HAE is a hereditary disease caused by deficiency or loss of C1 Inhibitor (C1-INH), with an autosomal dominant inheritance pattern and which may be potentially life threatening [3].

In this case report, 31 years old woman who has applied to the hospital with angioedema attack after odontotherapy and who had angioedema attacks for many years with abdominal symptoms in the forefront and as a consequence to whom laparotomy was applied 3 times, is discussed together with literature. 


\section{Case report}

In this case report, 31 years old woman who has applied to emergency department with complaints of swelling on face, eyelids and neck, shortness of breath, speech disorder, hoarseness that began a day after tooth extraction and that gradually increased. Oedema on face, eyelids and neck and hoarseness were detected during physical examination of the patient. There wasn't any color change and temperature rise at the oedematous regions. The oedema on face and eyelids of the patient are shown in Figure 1.

The anamnesis of the patient showed that she had complaints of swelling and pain on hands, feet and mostly on face many times, and complaint of recurrent long term abdominal pain and hence laparotomy was performed 3 times. It was determined that she received treatment for many years due to gastrointestinal and gynecological complaints and she still used oral contraceptives because of her gynecological complaints. The patient was taken into intensive care unit with pre-diagnosis of drug allergy, dental abscess, deep neck infection, cellulitis, angioedema. Intravenous hydration was applied after airway safety was obtained and she was monitored. $250 \mathrm{mg}$ metilprednisolon (Methylprednisolone Sopharma $125 \mathrm{mg}$ IM/IV Ampul. Vem Pharmacy. Istanbul, Turkey), $45.5 \mathrm{mg}$ feniramin maleat (Avil $2 \mathrm{~mL}, 45.5 \mathrm{mg}$ Ampul. Sandoz Pharmacy. Istanbul, Turkey.) was administered to the patient. The oedema on face and lips regressed at the $2^{\text {nd }}$ day after she was taken into intensive care unit. IgE level, $\mathrm{C} 4$ level were determined. IgE level was at normal limits and C4 level was $25 \%$ of the lower limit. In the detailed anamnesis obtained the patient stated that two daughters of her, her sister, the daughter of her sister, the brother of her, her mother, her uncle, and two sons of her uncle, two aunts and her grandfather also had the same complaints.. Her mother had swelling on her face and neck when she died. The family tree of the patient is presented in Table 1 .

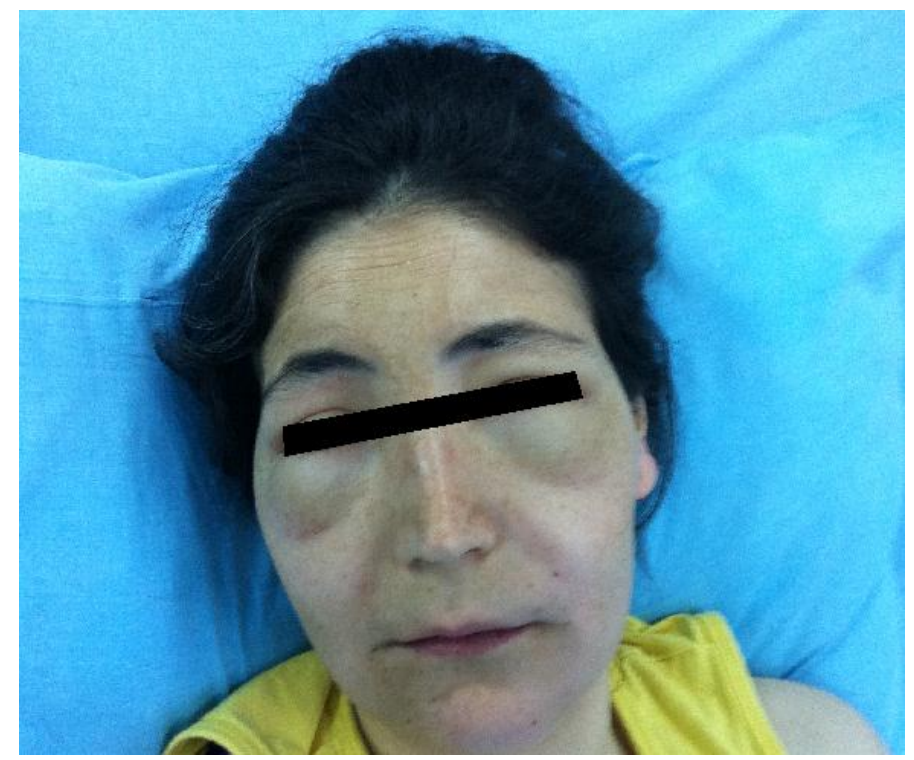

Figure 1. Facial oedema image of the patient.

$\mathrm{C} 4$ and IgE levels of 4 children of the patient were determined. While IgE levels of her two daughters who had complaints were normal, C4 levels of two daughters were $10 \%$ and $40 \%$ of lower limit. C1 esterase inhibitor levels of the patient and her two daughters were normal. HAE Type II diagnosis was established for the patient and her two daughters with clinical and laboratory findings. Oral contraceptive usage of the patient was terminated. The patient was sent to allergy and immunology physician for follow up and treatment upon complete improvement of complaints. C1-INH concentrate was started to the patient. The image of the patient after treatment is shown in Figure 2. 
Table 1. The family tree of the patient.

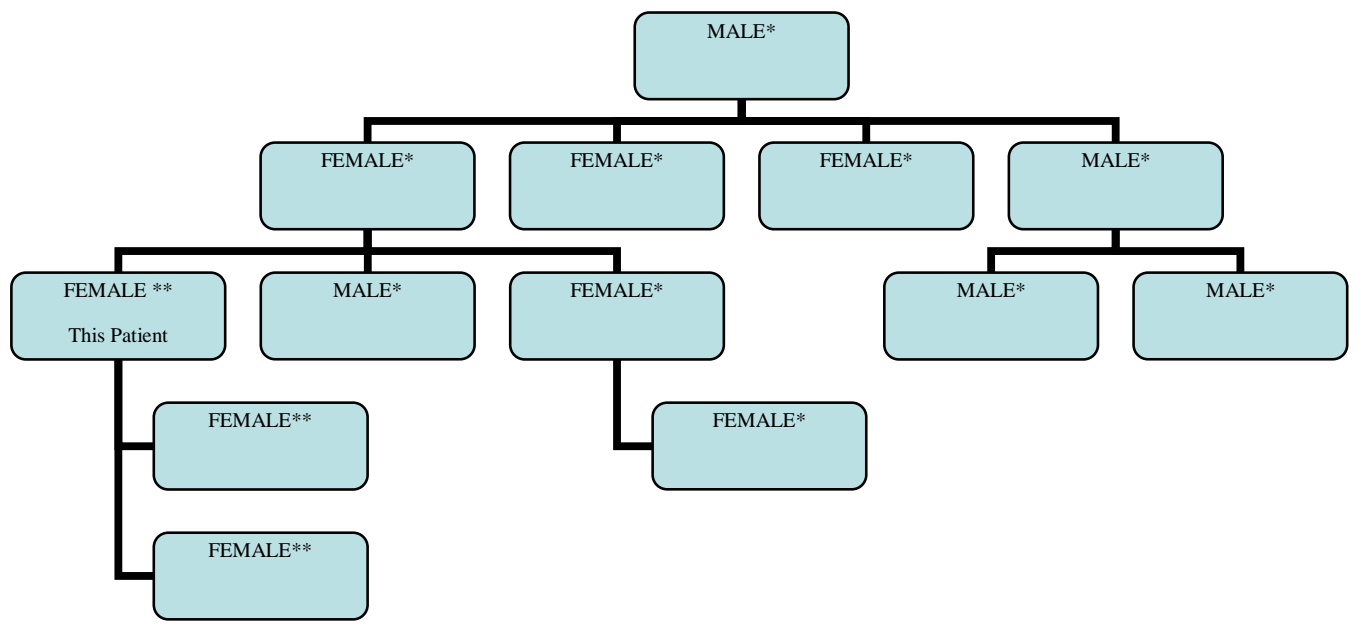

* Clinical Anamnesis Positive

** Clinical Anamnesis and Laboratory Positive

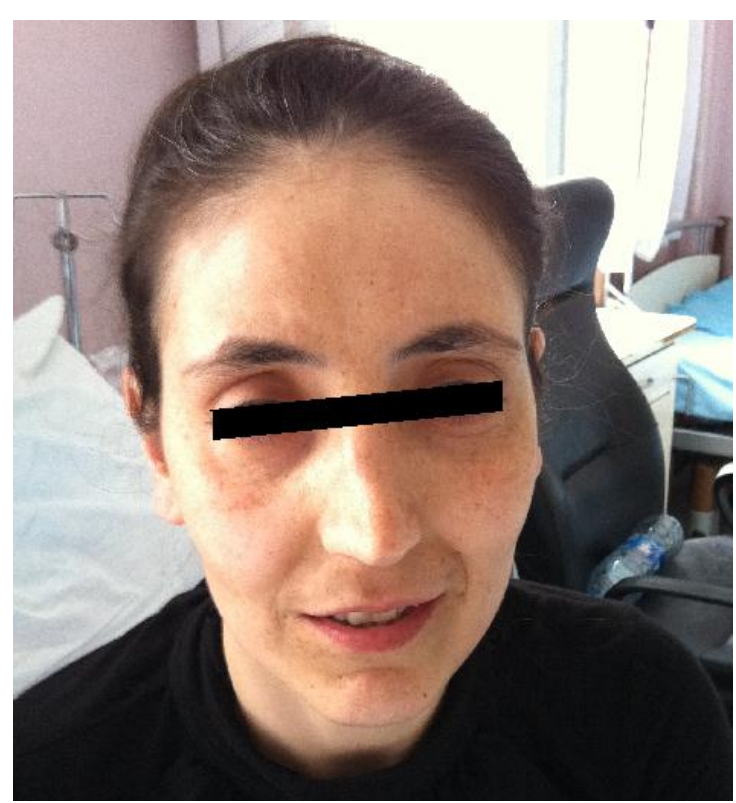

Figure 2. The image of the patient after treatment.

\section{Discussion}

Angioedema Type I-II and Type III HAE may be classified as C1-INH deficiency and Angiotensin Converting Enzyme- Inhibitor (ACE-INH) associated angioedema. Type I HAE and Type II constitute $80-85 \%$ and $10-15 \%$ of the cases, respectively and the others constitute a small part of the cases. C1-INH synthesis decreases in Type I HAE although C1-INH synthesis is normal in Type II, functional loss is seen due to enzyme defect. C1INH synthesis and function are normal in Type III HAE. Factor-XII gene defect exists. But there are no certain criteria for diagnosis. This especially affects women. C1-INH deficiency associated angioedema (AE) shows itself with Type I-II like angioedema attacks in middle aged individuals caused by over consumption. However ACE-Inhibitor (ACE-INH) associated AE must be taken into account for any patient using ACE-INH [1, 4]. The most important factor in diagnosis is clinical history. Non-prutiric oedema on skin develops and submucosa of various organs is affected in patients during attack [1]. Five percent of cases are asymptomatic. Skin oedema is seen especially on extremity, face, 
genital organs and body. Frequency of abdominal attack in edema episodes is extremely high $(97.4 \%)$. Besides laryngeal oedema $(0.9 \%)$, soft palate oedema $(0.6 \%)$, tongue oedema $(0.3 \%)$ and headache attacks $(0.9 \%)$ may be seen [5]. Bradykinin is a key mediator of symptoms of the disease [6]. Stress, trauma, alcohol drinking, estrogen, menstruation, viral infection, temperature changes, pregnancy, surgical and dental interventions may trigger HA attacks [1, 7]. Acute attacks after dental intervention has developed. Intestinal angioedema leads to unnecessary surgical intervention and correspondingly morbidity increase by causing temporary obstruction and abdominal pain that is confused with acute abdomen [8]. Due to the intestinal symptoms, laparotomy was performed 3 times. It should not be forgotten that delay in diagnosis increases morbidity and affects quality of life negatively. Oxygenation / saturation follow up, hydration, antispasmodic / analgesic when needed, cessation of ACE-INH if any, fresh frozen plasma, C1-INH concentrate, bradykinin receptor antagonist, kallikrein inhibitor androgens and fibrinolytic agents may be used for the treatment of the disease [1]. Danazol, stanozolol and methylestosterone used for the treatment of adults are not suggested for children due to their virilizing side effects. Therefore, oxandrolone with scarce virilizing side effects may be used safely [9]. Scheffer et al. [10] stated that short term (96 hours) tranexamic acid prophylaxy before surgical intervention was effective in preventing angioedema attacks.

It is stated that $\mathrm{C} 1-\mathrm{INH}$ concentrate used in HAE treatment, decreases the frequency of attacks [11]. Cinryze (Virofarma Biologics, Inc. USA.), that is a C1-INH preparation is not used in acute attack treatment while it is used in short term prophylaxis. The other C1-INH preparation, Berinert (CSL Behring. USA.) is used in acute attack treatment [1]. Low C4 levels are stated to be a very effective screen test in untreatable HAE cases and $\mathrm{C} 4$ levels are generally $30 \%$ lower than normal value [12]. Low C4 levels and normal C1 inhibitor levels were determined in this patient and in her two daughters and Type II HAE diagnosis was established.

In conclusion, HAE must certainly be considered for patients who apply with localized angioedema and especially with symptoms relating to upper airway tract and treatment strategy must be determined urgently. Besides, unnecessary laparotomies may be prevented in patients who are supposed to be with HAE by considering frequent abdominal attacks. It should not be forgotten that classical allergy-anaphylaxis treatment shall be ineffective and special treatment options must be evaluated for these patients.

\section{References}

1. Giavina-Bianchi P, França AT, Grumach AS, Motta AA, Fernandes FR, Campos RA, Valle SO, Rosário NA, Sole D. Brazilian Guidelines for the Diagnosis and Treatment of Hereditary Angioedema. Clinics 2011; 66: 1627-36.

2. Kasamatsu Y, Yoshinoya K, Kasamatsu Y, Yamamoto T, Horiuchi T, Kadoya M.A case of hereditary angioedema involving recurrent abdominal attacks. Intern Med 2011; 50: 2911-4.

3. Zurow BL. HAE Therapies: Past Present and Future. Allergy Asthma Clin Immunol 2010; 6: 23.

4. Zuraw BL, Christiansen SC. Pathophysiology of Hereditary Angioedema. Am J Rhinol Allergy 2011; 25: 373-8.

5. Bork K, Meng G, Staubach P, Hardt J. Hereditary angioedema: new findings concerning symptoms, affected organs, and course. Am J Med 2006; 119: 26774.

6. Cicardi M, Banerji A, Bracho F, Malbrán A, Rosenkranz B, Riedl M, Bork K, Lumry W, Aberer W, Bier H, Bas M, Greve J, Hoffmann TK, Farkas H, Reshef A, Ritchie B, Yang W, Grabbe J, Kivity S, Kreuz W, Levy RJ, Luger T, Obtulowicz K, Schmid-Grendelmeier P, Bull C, Sitkauskiene B, Smith WB, Toubi E, Werner S, Anné S, Björkander J, Bouillet L, Cillari E, Hurewitz D, Jacobson KW, Katelaris CH, Maurer M, Merk H, Bernstein JA, Feighery C, 
Floccard B, Gleich G, Hébert J, Kaatz M, Keith P, Kirkpatrick CH, Langton D, Martin L, Pichler C, Resnick D, Wombolt D, Fernández Romero DS, Zanichelli A, Arcoleo F, Knolle J, Kravec I, Dong L, Zimmermann J, Rosen K, Fan WT. Icatibant, a new bradykinin-receptor antagonist, in hereditary angioedema. $\mathrm{N}$ Engl J Med 2010; 363: 532-41.

7. Bork K. Recurrent angioedema and the threat of asphyxiation. Dtsch Arztebl Int 2010; 107: 408-14.

8. Locascio EJ, Mahler SA, Arnold TC. Intestinal Angioedema Misdiagnosed as Recurrent Episodes of Gastroenteritis. West J Emerg Med 2010; 11: 391-4.

9. Church JA. Oxandrolone Treatment of Chilhood Hereditary Angioedema. Ann Allergy Asthma Immunol 2004; 92: 377-8.

10. Sheffer AL, Fearon DT, Austen KF, Rosen FS. Tranexamic Acid: Preoperative Prophylactic Therapy for Patients with Hereditary Angioneurotic Edema. J Allergy Clin Immunol 1977; 60: 38-40.

11. Lyseng-Williamson KA. Nanofiltreted Human C1 Inhibitor Concentrate (Cinryze): In Hereditary Angioedema. Biodrugs 2011; 25: 317-27.

12. Gompels MM, Lock RJ, Morgan JE, Osborne J, Brown A, Virgo PF. A multicentre evaluation of the diagnostic efficiency of serological investigations for C1 inhibitor deficiency. J Clin Pathol 2002; 55: 145-7. 